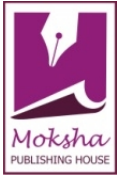

\author{
Review Article \\ www.ijrap.net
}

\title{
AN APPROACH TOWARDS UNDERSTANDING THE SCOPE OF SATKARYAVADA IN AYURVEDA: A REVIEW
}

Sharvari Ramakant Satkar ${ }^{1 *}$, B. K. Dwibedy ${ }^{2}$

${ }^{1}$ JR II, Department of Siddhant Darshan, Faculty of Ayurveda, IMS, BHU, Varanasi, Uttar Pradesh, India

${ }^{2}$ Professor and head, Department of Siddhant Darshan, Faculty of Ayurveda, IMS, BHU, Varanasi, Uttar Pradesh, India

Received on: 23/08/16 Revised on: 28/09/16 Accepted on: 04/10/16

\author{
*Corresponding author \\ E-mail: sharvarisatkar@gmail.com
}

DOI: 10.7897/2277-4343.075214

\section{ABSTRACT}

Satkaryavada is the theory which is adopted from Indian Philosophy i.e. samkhya darshana which has described cause and effect in a newer prospect that the concept of existence of effect (karya) in cause (karana) before its formation. Analogy of satkaryavada has been described along with its application in Ayurveda as the six factors in formation of foetus, sixteen factors in development of foetus (garbha vikasa), anomalies in foetus (garbha vikara), different congenital diseases (sahaj vikara) like arsha (piles), kushtha (skin diseases) etc., beejdosha vikara have been discussed with an approach to explore the theory of Satkaryavada in Ayurveda and it has been concluded that genetic theory of Ayurveda is based on Satkaryavada.

Keywords: Satkaryavada, beejdosha, karya, karana, garbhavikara, garbhavikasa

\section{INTRODUCTION}

Ayurveda is the science of normal and abnormal state of body and mind. This is the art of life style or living. Also, it is a philosophy to achieve the goals of life and beyond life. So, it has established on some philosophical backgrounds especially Saddarsanas of India. Ayurveda has applied the Sad-darsanas from health and clinical point of view. The Karyakaranavada, Satkaryavada are the basis of Ayurveda. Commonly, Ayurvedic scholars have also applied the Karyakaranavada and Satkaryavada in same manner and with same meaning. Here, we tried to search out the materials which were directly related to Satkaryavada.

Satkaryavada proposed the concept/theory of existence of effect (Karya) in cause (Karana) before its (effects) formation.

Sat - existent,

Karya - effect,

Vada - concept / theory

This concept was proposed by Samkhya philosopher and followed by its commentators. They denied the difference between cause and effect. As they stated that effect is the much expressed form of cause only. There is only difference of shape, size or function of both of them.Ayurveda has applied this theory in reference of Garbha vikasa which becomes as genetic theory of Ayurveda.

In reference of Garbha, the theory of Satkaryavada is applied in a broad way. The six different Bhavas for formation of 'Garbha' are based on this theory.

In favor of the theory of 'Satkaryavada' some arguments were given and it was explained with the help of 5 analogies, described in Samkhyatattwakaumudi as follows ${ }^{1}$ :

1) Asadakaranat - Which has no existence, is known as 'Asat'. 'Asat' has no capacity to produce anything. So, only existent cause (Karana) can produce existent effect (Karya). Just like there is no formation of oil from sand. It means that without existing source or causes any effect or Karya cannot be imaged.
2) Upadana grahanat- Here the cause or source of any Karya (effect) is regarded as 'Upadana'. In fact 'Karya' is a modification of cause or source, known as Upadana. Such as milk is Upadana Karana for curd. If milk is not available then there will be no formation of curd. Also, curd cannot be produced from other than milk, like water or anything else. So, curd is just a modification of milk. Without existence of Upadana, effect will not be produced. Just like that, sperm and ovum is the Upadana karana for the formation of embryo.

3) Sarvasambhav abhavat- Everything cannot be produced from everything and at everywhere. Such as gold, silver etc. cannot be obtained from grass, sand; soil etc. This argument has been given as 'sarvasambhavaabhavat', in favor of Satkaryavada, because a single source cannot be reformed into all effects (Karyas). Each and everything cannot be produced from the source at everywhere. It means specific source or specific cause becomes a specific effect or form which is known as 'Karya'.

4) Shaktasya shakyakaranat- Only potent cause is able to produce effect. Such as, with the help of water, clothe, rod, rope; a potter produces a pot by using soil as main content. With above things he will not produce anything else but pot only.

5) Karan bhavat- Properties possessed by cause are also present in effect. Such as, Yava (hordeum vulgare) is produced from Yava and possesses all properties of Yava only. Same thing is applied in production of Vreehi (oryza sativa). Also, Vreehi cannot be produced from Yava and doesn't possess properties of Yava.

\section{Application of Satkaryavada in Ayurveda}

\section{Bhava}

In reference of Garbha it has been stated that the combination of six different Bhavas are responsible for the formation of Garbha ${ }^{2}$.

Here the six factors Matrija, Pitrija, Aatmaja, Satmyaja, Rasaja, and Sattvaja etc are regarded as bhava which has meaning of 
existence $^{3}$. This refers to Sat. These six factors which are existent combine with each other and its effect is Garbha. These Bhavas having existence takes developed form in foetus.

\section{Shad-bhava (6 factors)}

The foetus is formed out of the combination of 6 factors ${ }^{4}$

1) Factors from mother

Foetus is produced out of mother. Without mother there is no possibility of conception and birth of viviparous. Twak (Skin), lohita (blood), mansa (flesh), meda (fat), nabhi (umbilicus), hridaya (heart), kloman, yakrita (liver), pleeha (spleen), vrikkou (kidneys), vasti (bladder), purisadhanam (rectum), amasaya (stomach), pakvasaya, uttar- adhargudah (upper and lower part ofanus), kshudrantra-brihadantra (small and large intestine), vapa (mesentery), vapavahanam (omentum) etc are derived from mother ${ }^{5}$.

2) Factors from father

Same as that of mother, without father there is no possibility of conception. Kesha -shmashru (Hairs on head and face), nakha (nails), loma (body hairs), danta ( teeth), asthi (bones), sirah (veins), snayu (ligaments), dhamanyah (arteries), sukra (semen) etc are derived from father ${ }^{6}$.

3) Factors from Atman

A particular effect is always produced from similar cause. According to Chakrapani, a sprout of Sana (Crotalaria juncia Linn.) does not come out of the Coconut seed. Same as that, the consciousness of the foetus does not come out from the Bhutas (elements) which by themselves are without consciousness. It comes from the soul which is conscious. Birth in a particular womb, Aayu (life span), Aatmagnyanam (self realization), Manas (mind), indriyani (senses), pranapanou ( intake and output from body), preranam (stimulation), dharanam (sustenance of sense organs), Aakriti( shape), swara (voice), varna (complexion of individual), sukha-dukkha (desire of happiness and sorrow), ichha-dvesha (liking and disliking), cetana (consciousness), dhriti (courage), buddhi (intellect), smriti (memory), ahamkara (egoism), prayatna (efforts) etc are derived from Atman?

4) Factors derived from Satmya

Human beings are capable of procreating offspring as long as the sperm of man, ovum and uterus of woman are not afflicted by the circulation of the three Dosas (vitiating elements), which are mainly vitiated by the intake of unwholesome things. Aarogyam (Healthiness), analasyaalolupatva (lack of laziness and greed), indriyaprasada (clarity of senses), swara-varna-beejasampat (excellence of voice, complexion and seeds), and praharsa (excessive sex vigor) are the factors derived from Satmya ${ }^{8}$.

5) Factors derived from Rasa

Even without Rasa, mother will not survive and thus there will be no formation and nourishment of foetus. Sariraabhinirvritti-abhivriddhi (Manifestation and growth of body), prananubandha (continuity of strength), tripti (satisfaction), pusti (plumpness), utsaha (enthusiasm) etc are the factors derived from Rasa 9 .

6) Factors derived from Sattva

Mana (mind) is a connecting link between soul and physical body. Also, sense organs derive their inspiration from nothing but Manas (mind). Bhakti (Likings), sheela (conduct), shoucha (purity), dvesha (enmity), smriti (memory), moha (attachment), tyaga (detachment), matsarya (strong desire not to part with), shourya (velour), bhaya (fear), krodha (anger), tandra (drowsiness), utsaha (enthusiasm), tikshna (sharpness), mardavta (softness), gambhirya (seriousness), anavasthitattva (instability) of such other manifestations of Mana (mind) etc are the factors derived from Mana (mind) ${ }^{10}$.
In reference of Yukti pramana used to prove rebirth 'Satkaryavada' is applied ${ }^{11}$. The result come out of the action performed. There will be no germination without a seed. The result is always corresponding to the action. A seed cannot bring out heterogeneous products.

Thus, the results like offspring and wealth attained in this life can be explained only by taking resource to corresponding virtuous acts performed in the previous life. For there can be no germination of a heterogeneous product like barley from the seed of rice.

\section{Shodash Bhutas (16 factors)}

A special concept about origin contents of body in Garbha has been given in Charak samhita based on mahabhutas. Total numbers of Bhutas which take part in constitution of body in Garbha are sixteen and are classified in four groups i.e. Matrija, Pitrija, Rasaja and Aatmaja ${ }^{12}$.

Each 4 again contains 4 Bhutas-

1-Prithwi

2-Jala

3- Agni

4-Vayu

Thus total 16 in number. These Bhutas exist in Garbha and takes part to develop the embryo accompanying with the soul. Its existence depends upon contact with the soul, the 4 Bhutas of Matrija (through ovum) and Pitrija (through shukra or sperm) ${ }^{13}$. In other reference it is also stated that the Bhavas of Matrija, Pitrija etc. are also mahabhuta-vikaras. It means organs, organelles etc. are developed by ovum or sperm are virtually vikaras of mahabhutas only ${ }^{14}$.

In fact, organs or organelles are constituted by Mahabhutas of these 4 groups only. Here, Rasaja bhava is considered as final product of food taken by pregnant lady. It has no independent role in development of Garbha or it does not affect the Garbha directly. The Mahabhutas derived from Rasa gives support and nourishment to the Bhautika content of Shukra (sperm) and Sonita (ovum) ${ }^{15}$.

The $4^{\text {th }}$ group of Bhutas is regarded as Aatmaja bhava. Here, this Aatmaja bhava may be considered along with the bhutas or the factor lingasarira, ativahika purusa, suksmasarira. As stated in reference of transmigration. Also, the 4 Bhutas which get fused with the soul to enter into the foetus are the products of past actions. Continuity of the migration of Bhutas is maintained as the soul who is like a seed transmigrates from one body to another ${ }^{16}$. In this regard, there is very important point where this lingasarira or group of 4 Bhutas is regarded as having beejadharma i.e. having specific role in development of embryo just like seed. The development of embryo will depend on existing factors in Aatmaja bhava.

It is also stated in scriptures (especially in Samkhya) that this gross body is the product of the subtle body (suksmasarira). The sperm and ovum, after their combination, can manifest a gross body in the form of foetus, only when the subtle body (suksmasarira) is associated with them. This association or combination of subtle body with the sperm and ovum is conditioned by the past actions. The cause and effect always bear resemblance with each other. The color of clothe is dependent on the color of the threads composing clothe. Similarly, the characteristic features of gross body resemble those of the subtle body. Not only the physique but also the mental faculties of an individual resemble those of the subtle body ${ }^{17}$.

\section{Garbha vikas (development of foetus)}

The soul desirous of creating an embryo, first of all, unites with akasa mahabhuta. His union with other grosser mahabhutas is of course completed in a very short time ${ }^{18}$. 
Table 1

\begin{tabular}{|c|l|}
\hline $1^{\text {st }}$ month & $\begin{array}{l}\text { When accompanied with all the attributes, the soul, takes the form of an embryo. During the first month of gestation, it takes } \\
\text { the form of jelly because of the intimate mixture of five mahabhutas. During this month the embryo bears no particular } \\
\text { shape and form and the organs of the embryo are both manifested and latent. }\end{array}$ \\
\hline $2^{\text {nd }}$ month & $\begin{array}{l}\text { During } 2^{\text {nd }} \text { month of gestation, the embryo takes a compact form in the shape of a knot, elongated muscle or tumor. } \\
\text { Pinda (Knot) shaped- male foetus production } \\
\text { Peshi (Muscle) shaped-female foetus production } \\
\text { Arbuda (Tumor) shaped-eunuch foetus production }\end{array}$ \\
\hline $3^{\text {rd }}$ month & All the senses and limbs along with their organs are manifested simultaneously. \\
\hline $4^{4 \text { th }}$ month & The foetus gets stabilized. Therefore at that time pregnant woman specifically gets excessive heaviness in her body. \\
\hline $5^{\text {th }}$ month & Excessive increase in flesh and blood of foetus. So, mother gets thinner excessively. \\
\hline $6^{\text {th }}$ month & Excessive increase in strength and complexion of foetus. So, mother loses her strength and complexion considerably. \\
\hline $7^{\text {th }}$ month & All around development of foetus takes place. So, mother becomes exceedingly deficient in all aspects of her health. \\
\hline $8^{\text {th }}$ month & $\begin{array}{l}\text { Ojas is unstable, moving from body of mother to foetus and vice versa. So, mother has wavering feelings of joy and sorrow. } \\
\text { Same in foetus also. So due to this unsteadiness of ojas, delivery during this month is shrouded with danger. So, reckoning } \\
\text { of the } 8^{\text {th }} \text { month of pregnancy should be avoided. }\end{array}$ \\
\hline $9^{\text {th }}$ month & $\begin{array}{l}\text { Even the } 1^{\text {st }} \text { day after the } 8^{\text {th }} \text { month i.e. from the } 1^{\text {st }} \text { day of } 9^{\text {th }} \text { month till the end of } 10^{\text {th }} \text { month is known as period of } \\
\text { parturition. Normally delivery takes place during this period. }\end{array}$ \\
\hline
\end{tabular}

This is the description of successive manifestations of the foetus in womb ${ }^{19}$.

Table 2: Factors responsible for abnormality in fetus

\begin{tabular}{|c|c|}
\hline Because of the & seed (sperm and ovum) \\
\cline { 2 - 2 } defects in & actions associated with the soul \\
\cline { 2 - 2 } & Uterus \\
\cline { 2 - 2 } & Time \\
\cline { 2 - 2 } & Food taken by mother \\
\cline { 2 - 2 } & and other regimen of mother \\
\hline
\end{tabular}

Dosas (vitiating elements) get variously vitiated. This results in the impairment of shape, color, sensory and motor organs of offspring. ${ }^{20}$

As a tree standing in a current of a river gets afflicted by the forceful downward movement of wood, stone pieces and the water during the rainy season. So, the foetus in the uterus of the mother gets afflicted with the vitiated Dosas (vitiating elements) 21 .

\section{Vikriti (abnormality)}

There are three physical and two mental Dosas (vitiating elements). Vitiation of body and Manas (mind) due to these Dosas (vitiating elements) results in the manifestation of diseases and vice versa ${ }^{22}$.

These vitiated Dosas (vitiating elements) may afflict the Beeja, BeejabhagavaYava, Beejabhaga avayava ekdesha by which the corresponding organ is derived, get deformed ${ }^{23}$.

1. Vitiation of Beejabhaga- deformity in male and female foetus will be sterility.

2. Vitiation of Beejabhaga avayava- deformity in female and male foetus will be Putipraja.

3. Vitiation of Beejabhaga avayava ekdesha - deformity in female foetus will be Varta and in male foetus will be Trinaputrika.

\section{Vyadhi (diseases)}

\section{Yonivyapada (gynecic morbidities)}

The vayu in the foetus destroys the developing organs in the womb of the mother due to the gynecic morbidity, Here this genetic morbidity specifically refers to that of the mother i.e. ovum $^{24}$. The genetic morbidity of ovum stated to be responsible for the destruction of uterus of female foetus ${ }^{25}$.

\section{Arsha (piles)}

Hereditary piles are caused by the vitiation of seeds (sperm and ovum), especially that part of the seed which is responsible for the formation of the anal sphincters ${ }^{26}$.

Vitiation of seed can be caused by two factors first wrong diet and regimen of father and mother and second sinful acts of past life. These two categories of causative factors are applicable to all other hereditary diseases also ${ }^{27}$.

Kushth (skin diseases)

A child who is the offspring of the contaminated sperm and ovum of the parents afflicted with Kushth (skin diseases) should be likewise regarded as Kushthi ${ }^{28}$.

\section{Table 3: Sex deformities in fetus}

\begin{tabular}{|l|l|}
\hline $\begin{array}{l}\text { Dwiretas } \\
\text { (hermaphrodism) }\end{array}$ & $\begin{array}{l}\text { When the portion of the sperm and ovum of } \\
\text { parents which is responsible for the formation } \\
\text { of the genital cells of the foetus get vitiated } \\
\text { and these sperm and ovum undergo equal } \\
\text { division, then the offspring becomes a } \\
\text { hermaphrodite having characteristic features } \\
\text { of both the sexes. }\end{array}$ \\
\hline Pavanendriyatva & $\begin{array}{l}\text { If the testicles (reservoirs of sperm) of the } \\
\text { foetus are afflicted with vata, then the } \\
\text { offspring becomes aspermic. }\end{array}$ \\
\hline Samskarvahi & $\begin{array}{l}\text { Obstruction of seminal passage by vata makes } \\
\text { the offspring Samskaarvahi. }\end{array}$ \\
\hline $\begin{array}{l}\text { Nara sandha } \\
\text { (male sterility) }\end{array}$ & $\begin{array}{l}\text { The congenital lack of strength and passion } \\
\text { results in impairment and insufficiency of } \\
\text { sperm which in turn leads to male sterility. }\end{array}$ \\
\hline $\begin{array}{l}\text { Nari sandha (male } \\
\text { sterility) }\end{array}$ & $\begin{array}{l}\text { The congenital lack of strength and passion } \\
\text { results in impairment and insufficiency of } \\
\text { ovum which in turn leads to female sterility. }\end{array}$ \\
\hline $\begin{array}{l}\text { Vakri } \\
\text { (hypospadiac) }\end{array}$ & $\begin{array}{l}\text { Weakness in sperms of male partner and } \\
\text { irregular posture of female partner during } \\
\text { coitus make the offspring hypospadiac. }\end{array}$ \\
\hline $\begin{array}{l}\text { Irsyabhirati } \\
\text { (mixoscopia) }\end{array}$ & $\begin{array}{l}\text { Reduced passion along with jealousy of the } \\
\text { parent's cohabitation produces mixoscopia in } \\
\text { the offspring. }\end{array}$ \\
\hline $\begin{array}{l}\text { Vatikasandaka } \\
\text { (eviration) }\end{array}$ & $\begin{array}{l}\text { Being affected by vayu and agni (pitta) if the } \\
\text { testicles of the foetus get destroyed, then } \\
\text { there is eviration in offspring. }\end{array}$ \\
\hline
\end{tabular}

These are 8 types of sexual abnormalities ${ }^{29}$. They are caused by the effects of misdeeds in the previous life of individual.

\section{DISCUSSION}

The two theories Satkaryavada and Karyakaranavada are existed and applied in same meaning in Ayurveda. Satkaryavada is explained by Samkhya and Karyakaranavada by Nyaya philosophers. Commonly both theories are applied with sligh difference. Here content of discussion is Satkaryavada which has meaning 'existence theory of karya'. According to this theory, karya is present in karana which is unexpressed form. There is only development or modification of karya. In fact if we observe, the term which indicates there is only existence of karya and cause has not been considered. While the theory of 
Nyaya- Karyakaranavada is causative theory. According to this theory, any effect is not possible without cause, while Satkkaryavada indicates effect is existed and takes developed or modified form only. It is then known as effect or creation. But in fact, there is no creation or production. There is only modification and development. This theory indicates the Upadana Karana which is considered as effect in Samkhya. Also Karyakaranavada is based on analysis of different 'causes'. This theory is applied in Ayurveda in reference of Garbh nirmaan and Vikasa. In other words it may be said Beejavada which is basis of genetic theory. This theory is described in two ways i.e. shad bhava and shodash bhava. According to Shad bhava each and every factor of foetus is existed in Matrijadi bhavas. If any content of any organ, factor does not exist in beeja then there is no development of that particular organ or there may be abnormality in that particular organ. Same theory is also applied in shodash bhavas. Thus 16 mahabhutas takes part in the formation of foetus and according to their dominance, organ develops. It is clearly mentioned in reference of fetal development that in first month the organs exist in Kalala form and cannot be differentiated due to undeveloped form but the all factors are maintained in kalala in unexpressed form. Gradually there is fetal development and organs, shape, color etc which existed in beeja, takes gross form. If a factor (responsible for a particular organ formation) in beeja is not present or existed then there will be no formation of that particular organ. If factor is abnormal, there will be abnormality in the organ as explained in Arsha (piles) and Yonivyapada (gynecic morbidities). In reference of genetic theory according to ayurveda, it has been clearly stated that vitiated dosas (elements) may afflict the Beeja, Beejabhagavayava, Beejabhaga avayava ekdesha by which the corresponding organ is derived, get deformed. And based on this theory some abnormalities are explained accordingly.

\section{CONCLUSION}

Satkaryavada is existence theory of effect. Effect always exists and not produced. Thus genetic theory of Ayurveda is based on Satkaryavada. Satkaryavada has applied and clinical aspects. The theory of Beeja or Beejavada is also based on Satkaryavada. Some specific types of diseases are explained on the basis of this theory. This is the primary level study on Satkaryavada which may indicate a broad way for further research.

\section{REFERENCES}

1. Shukl Vageeshwar Vaidya. Padarthvijnyanam. Revised ed 2004. Choukhamba Bharti Academy; Samkhyakhandam, satkaryavada ,p.146-147

2. Sharma R.K., Baghwan Dash. Editor. Caraka Samhita-text with English translation and critical exposition based on Chakrapani Datta's 'Ayurved Dipika'. Choukhamba Sanskrit series Varanasi; 2009. volume 2, Ch.Sha.3/5, p.370

3. Sharma R.K., Baghwan Dash. Editor. Caraka Samhita-text with English translation and critical exposition based on Chakrapani Datta's 'Ayurved Dipika'. Choukhamba Sanskrit series Varanasi; 2009. volume 2, Ch.Sha.4/4, p.387

4. Sharma R.K., Baghwan Dash. Editor. Caraka Samhita-text with English translation and critical exposition based on Chakrapani Datta's 'Ayurved Dipika'. Choukhamba Sanskrit series Varanasi; 2009. volume 2, Ch.Sha.3/5, p.370

5. Sharma R.K., Baghwan Dash. Editor. Caraka Samhita-text with English translation and critical exposition based on Chakrapani Datta's 'Ayurved Dipika'. Choukhamba Sanskrit series Varanasi; 2009. volume 2, Ch.Sha.3/6, p.370

6. Sharma R.K., Baghwan Dash. Editor. Caraka Samhita-text with English translation and critical exposition based on
Chakrapani Datta's 'Ayurved Dipika'. Choukhamba Sanskrit series Varanasi; 2009. volume 2, Ch.Sha.3/7, p.371

7. Sharma R.K., Baghwan Dash. Editor. Caraka Samhita-text with English translation and critical exposition based on ChakrapaniDatta's 'AyurvedDipika'. Choukhamba Sanskrit series Varanasi; 2009. volume 2, Ch.Sha.3/8, p.372

8. Sharma R.K., Baghwan Dash. Editor. Caraka Samhita-text with English translation and critical exposition based on ChakrapaniDatta's 'AyurvedDipika'. Choukhamba Sanskrit series Varanasi; 2009. volume 2, Ch.Sha.3/11, p.376

9. Sharma R.K., Baghwan Dash. Editor. Caraka Samhita-text with English translation and critical exposition based on Chakrapani Datta's 'Ayurved Dipika'. Choukhamba Sanskrit series Varanasi; 2009. volume 2, Ch.Sha.3/12, p. 377

10. Sharma R.K., Baghwan Dash. Editor. Caraka Samhita-text with English translation and critical exposition based on Chakrapani Datta's 'Ayurved Dipika'. Choukhamba Sanskrit series Varanasi; 2009. volume 2, Ch.Sha.3/12, p. 378

11. Sharma R.K., Baghwan Dash. Editor. Caraka Samhita-text with English translation and critical exposition based on Chakrapani Datta's 'Ayurved Dipika'. Choukhamba Sanskrit series Varanasi; 2009. volume 1, Ch.Su.11/32, p. 218

12. Sharma R.K., Baghwan Dash. Editor. Caraka Samhita-text with English translation and critical exposition based on Chakrapani Datta's 'Ayurved Dipika'. Choukhamba Sanskrit series Varanasi; 2009. volume 2, Ch.Sha.2/26, p. 357

13. Sharma R.K., Baghwan Dash. Editor. Caraka Samhita-text with English translation and critical exposition based on Chakrapani Datta's 'Ayurved Dipika'. Choukhamba Sanskrit series Varanasi; 2009. volume 2, Ch.Sha.2/33, p. 360

14. Sharma R.K., Baghwan Dash. Editor. Caraka Samhita-text with English translation and critical exposition based on Chakrapani Datta's 'Ayurved Dipika'. Choukhamba Sanskrit series Varanasi; 2009. volume 2, Ch.Sha.4/12, p.392

15. Sharma R.K., Baghwan Dash. Editor. Caraka Samhita-text with English translation and critical exposition based on Chakrapani Datta's 'Ayurved Dipika'. Choukhamba Sanskrit series Varanasi; 2009. volume 2, Ch.Sha.2/34, p.360

16. Sharma R.K., Baghwan Dash. Editor. Caraka Samhita-text with English translation and critical exposition based on Chakrapani Datta's 'Ayurved Dipika'. Choukhamba Sanskrit series Varanasi; 2009. volume 2, Ch.Sha.2/35, p.360

17. Sharma R.K., Baghwan Dash. Editor. Caraka Samhita-text with English translation and critical exposition based on Chakrapani Datta's 'Ayurved Dipika'. Choukhamba Sanskrit series Varanasi; 2009. volume 2, Ch.Sha.2/4 commentary, p.361

18. Sharma R.K., Baghwan Dash. Editor. Caraka Samhita-text with English translation and critical exposition based on Chakrapani Datta's 'Ayurved Dipika'. Choukhamba Sanskrit series Varanasi; 2009. volume 2, Ch.Sha.4/8, p.390

19. Sharma R.K., Baghwan Dash. Editor. Caraka Samhita-text with English translation and critical exposition based on Chakrapani Datta's 'Ayurved Dipika'. Choukhamba Sanskrit series Varanasi; 2009. volume 2, Ch.Sha.4/9-25, p.391-400

20. Sharma R.K., Baghwan Dash. Editor. Caraka Samhita-text with English translation and critical exposition based on Chakrapani Datta's 'Ayurved Dipika'. Choukhamba 
Sanskrit series Varanasi; 2009. volume 2, Ch.Sha.2/29, p.359

21. Sharma R.K., Baghwan Dash. Editor. Caraka Samhita-text with English translation and critical exposition based on Chakrapani Datta's 'Ayurved Dipika'. Choukhamba Sanskrit series Varanasi; 2009. volume 2, Ch.Sha.2/30, p. 359

22. Sharma R.K., Baghwan Dash. Editor. Caraka Samhita-text with English translation and critical exposition based on Chakrapani Datta's 'Ayurved Dipika'. Choukhamba Sanskrit series Varanasi; 2009. volume 2, Ch.Sha.4/34, p.405

23. Sharma R.K., Baghwan Dash. Editor. Caraka Samhita-text with English translation and critical exposition based on Chakrapani Datta's 'Ayurved Dipika'. Choukhamba Sanskrit series Varanasi; 2009. volume 2, Ch.Sha.4/30-31, p. $402-404$

24. Sharma R.K., Baghwan Dash. Editor. Caraka Samhita-text with English translation and critical exposition based on Chakrapani Datta's 'Ayurved Dipika'. Choukhamba Sanskrit series Varanasi; 2009. volume 5, Ch.chi.30/34, p. 138

25. Sharma R.K., Baghwan Dash. Editor. Caraka Samhita-text with English translation and critical exposition based on Chakrapani Datta's 'Ayurved Dipika'. Choukhamba
Sanskrit series Varanasi; 2009. volume 2, Ch.Sha.4/30, p. 402

26. Sharma R.K., Baghwan Dash. Editor. Caraka Samhita-text with English translation and critical exposition based on Chakrapani Datta's 'Ayurved Dipika'. Choukhamba Sanskrit series Varanasi; 2009. volume 3, Ch.chi.14/5, p.574

27. Sharma R.K., Baghwan Dash. Editor. Caraka Samhita-text with English translation and critical exposition based on Chakrapani Datta's 'Ayurved Dipika'. Choukhamba Sanskrit series Varanasi; 2009. volume 3, Ch.chi.14/5, p.575

28. Sharma P. V. editor. Susruta Samhita with English translation of text and Dalhana's commentary along with critical notes. Choukhamba Vishwabharati Academy; Varanasi; reprint2010. volume 2, Su.Ni.5/28, p.42

29. Sharma R.K., Baghwan Dash. Editor. Caraka Samhita-text with English translation and critical exposition based on Chakrapani Datta's 'Ayurved Dipika'. Choukhamba Sanskrit series Varanasi; 2009. volume 2, Ch.Sha.2/18-21, p. 355

\section{Cite this article as:}

Sharvari Ramakant Satkar, B. K. Dwibedy. An approach towards understanding the scope of satkaryavada in Ayurveda: A review. Int. J. Res. Ayurveda Pharm. Sep - Oct 2016;7(Suppl 4): 31-35 http://dx.doi.org/10.7897/2277-4343.075214

Disclaimer: IJRAP is solely owned by Moksha Publishing House - A non-profit publishing house, dedicated to publish quality research, while every effort has been taken to verify the accuracy of the content published in our Journal. IJRAP cannot accept any responsibility or liability for the site content and articles published. The views expressed in articles by our contributing authors are not necessarily those of IJRAP editor or editorial board members. 